\title{
Fungicide evaluation for control of powdery mildew, Leveillula taurica (Lev.) Arn., of peppers in Puerto Rico'
}

\author{
José A. Negrón,' Rocío Rodriguez" and Lucas Avilés"
}

\begin{abstract}
The effectiveness of benomyl, chlorothalonil, copper hydroxide, dinocap, sulfur and triadimefon for the control of the fungus Leveillula iaurica, causal agent of the powdery mildew of peppers (Capsicum annuum), was evaluated under field conditions. Results from two experiments indicate that weekly applications of benomyl and triadimefon reduced disease incidence and increased pepper yield. In the first experiment, plots treated with triadimefon $(0.35 \mathrm{Lha})$ and benomyl $(0.55 \mathrm{~kg} / \mathrm{ha})$ produced 20.2 and $17.2 \mathrm{~kg}$ fruit/plot, respectively, whereas the nontreated plots yielded $13.9 \mathrm{~kg} / \mathrm{plot}$. A similar trend but with higher yields was obtained in the second experiment. Treatments with triadimefon 10.70 U/ha) and benomyl $(0.55 \mathrm{~kg} / \mathrm{ha})$ produced 41.0 and $41.3 \mathrm{~kg}$ of fruit/plot, respectively, as compared with the control treatments which yielded 29.0 $\mathrm{kg} / \mathrm{plot}$.
\end{abstract}

\section{RESUMEN}

Fungicidas evaluados para combatir el añublo polvoriento en pimiento

Se evaluó bajo condiciones de campo la eficacia de los fungicidas benomyl, hidróxido de cobre, dinocap, azufre y triadimefon para combatir el añublo polvoriento del pimiento (Leveillula taurica). Los resultados obtenidos demuestran que las aplicaciones semanales de los fungicidas benomyl y triadimefon reprimieron el patógeno, aminoraron la severidad de infección y aumentaron significativamente el rendimiento. En la primera prueba se obfuvieron rendimientos de 20.2 y $17.2 \mathrm{~kg}$./parcela con aplicaciones de triadimefon $(0.35 \mathrm{~L}$./ha.) y benomyl $(0.55 \mathrm{~kg} . / \mathrm{ha}$.), respectivamente, mientras que en las parcelas sin tratar el rendimiento obtenido fue de $13.9 \mathrm{~kg}$. En la segunda prueba, aun cuando los resultados fueron similares a los anteriores, se obtuvieron mejores rendimientos. Se obtuvieron rendimientos de 41.0 y $41.3 \mathrm{~kg}$. en parcelas tratadas con triadimefon ( $0.70 \mathrm{~L}$./ha.) y benomyl $(0.55 \mathrm{~kg} . / \mathrm{ha}$.); en las parcelas sin tratar se obtuvo un rendimiento de $29.0 \mathrm{~kg} . / \mathrm{ha}$.

\section{INTRODUCTION}

Peppers (Capsicum annuum) are the second most important vegetable crop in Puerto Rico, with a current value of $\$ 3.5$ million. In 1984-85, pepper production amounted to 146 million pounds, an increase of 75

\footnotetext{
'Manuscript submitted to Editorial Board 6 October 1988.

"Research Assistant, Department of Crop Protection.

"Assistant Phytopathologist, Department of Crop Protection.

Research Assistant, Department of Horticulture.
} 
percent over the $1980-81$ crop. Approximately $80 \%$ are produced on the south coast (2).

Powdery mildew of peppers, caused by the fungus Leveillula taurica (Leveille) Arnauld, is becoming a prevalent disease in Puerto Rico. During the dry season, outbreaks can begin as early as 2 weeks after transplanting. Yield losses of $40 \%$ can occur in severely affected fields.

The first visible symptom of the disease is the appearance of yellowish spots on the upper surface of the leaf (3). These spots are subtended by fungal structures on the leaf underside. Induced symptoms such as leaf curling expose the underleaf to the sun and alter normal photosynthetic functions. The quality and quantity of fruit is reduced. In severely affected plants defoliation occurs (10).

Since this is a relatively new disease in Puerto Rico, effective control measures are not available. This study was conducted to evaluate the potential of certain fungicides as a suitable control measure under our conditions.

\section{MATERIALS AND METHODS}

Two field experiments were established in a San Antón (Cumulic Haplustolls) silt-loam soil ( $\mathrm{pH}$ 7.7) at the Agricultural Experiment Substation, located in semiarid, southern plains of Puerto Rico. Experimental plots consisted of four rows, each $0.91 \mathrm{~m}$ wide and $4.6 \mathrm{~m}$ long. Fortyfive day-old plants of pepper cv. Blanco del País were transplanted at $0.3 \mathrm{~m}$ spacing. Overhead irrigation was applied immediately after planting. Thereafter, furrow irrigation was applied as needed.

In the first experiment, the fungicides chlorothalonil (2.65 and 5.32 $\mathrm{L} / \mathrm{ha}$ ), copper hydroxide (1.11 and $2.22 \mathrm{~kg} / \mathrm{ha}$ ), dinocap (0.42 and 0.84 $\mathrm{L} / \mathrm{ha})$, triadimefon $(0.35$ and $0.70 \mathrm{~L} / \mathrm{ha})$, benomyl $(0.55$ and $1.11 \mathrm{~kg} / \mathrm{ha})$ and sulfur (2.22 and $3.33 \mathrm{~kg} / \mathrm{ha}$ ) were applied as foliar sprays on a weekly basis for 8 weeks. Treatments were initiated 3 weeks after the appearance of the first symptoms.

In the second experiment, dinocap was substituted for water sprayed either once or twice a week. Spraying was begun immediately after appearance of the first symptoms of the disease.

Treatments were replicated four times in a randomized complete block arrangement. The number and weight of fruits harvested were recorded at harvest time (100 days after planting). Using Duncan's Multiple-range test we subjected yield data to analysis of variance and compared the means.

Disease ratings based on a qualitative assessment of fungal external colonization were tabulated on a numerical scale of 0 to 3 , in which 0 denoted an absence of external mycelia, $1=$ low, $2=$ moderate, and 3 $=$ high colonization of the lower leaf surface.

Increments in the yield of peppers were calculated by the following equation: 
$\%$ increment $=\frac{\text { weight of treated peppers minus weight of control }}{\text { weight of control }} \times 100$

Management practices followed AES-UPR recommendations for pepper production (1).

\section{RESULTS AND DISCUSSION}

In both trials fungicide treatments were generally effective in controlling $L$. taurica. The most effective disease control was obtained in plots treated with benomyl and triadimefon, at all rates tested, as evidenced by lower disease rating (table 1 ).

TABLE 1.-Effects of fungicides on the incidence of powdery mildew in peppers, and on the yield of infected pepper plants under semi-arid conditions in Prerto Rico, 1984 and 198.5

\begin{tabular}{|c|c|c|c|c|c|c|}
\hline \multirow[b]{2}{*}{ Treatment } & \multirow{2}{*}{$\begin{array}{l}\text { Rate } \\
\text { ha }\end{array}$} & \multicolumn{4}{|c|}{ Fruits/plot } & \multirow{2}{*}{$\begin{array}{c}\text { Disease } \\
\text { rating }\end{array}$} \\
\hline & & Number' & Increment & Weight' & Increment & \\
\hline & \multicolumn{6}{|c|}{1984 Crop } \\
\hline Triadimefon & 0.351 & $527 a^{2}$ & 63.7 & $20.2 \mathrm{a}$ & 45.3 & 1.0 \\
\hline Triadimefon & 0.701 & 393 de & 22.0 & $15.6 \mathrm{de}$ & 12.2 & 1.3 \\
\hline Benomyl & $0.55 \mathrm{~kg}$ & $442 \mathrm{~b}$ & 37.3 & $17.2 \mathrm{bc}$ & 23.7 & 1.0 \\
\hline Benomyl & $1.11 \mathrm{~kg}$ & $437 \mathrm{bc}$ & 35.7 & $17.2 b c$ & 23.7 & 1.0 \\
\hline Sulfur & $2.22 \mathrm{~kg}$ & $357 \mathrm{fg}$ & 10.9 & 16.4 bed & 18.0 & 2.5 \\
\hline Sulfur & $3.33 \mathrm{~kg}$ & 389 def & 20.8 & $15.9 \mathrm{~cd}$ & 14.4 & 2.8 \\
\hline Copper hydroxide & $1.11 \mathrm{~kg}$ & $406 \mathrm{~cd}$ & 26.1 & $14.3 \mathrm{ef}$ & 2.9 & 2.8 \\
\hline Copper hydroxide & $2.22 \mathrm{~kg}$ & 312 hi & -3.1 & $12.7 \mathrm{~g}$ & -8.6 & 2.8 \\
\hline Chlorothalonil & $2.65 \mathrm{l}$ & 368 efg & 14.3 & $15.4 \mathrm{de}$ & 10.8 & 2.0 \\
\hline Chlorothalonil & 5.321 & $307 \mathrm{i}$ & -4.7 & $14.3 \mathrm{ef}$ & 2.9 & 2.5 \\
\hline Dinocap & 0.421 & 389 def & 20.8 & $17.5 \mathrm{~b}$ & 26.0 & 3.0 \\
\hline Dinocap & 0.841 & $34 \mathrm{lgh}$ & 5.9 & $12.9 \mathrm{fg}$ & -7.2 & 3.0 \\
\hline \multirow[t]{2}{*}{ Check } & & 322 hi & & $13.9 \mathrm{fg}$ & & 3.0 \\
\hline & \multicolumn{6}{|c|}{1985 Crop } \\
\hline Triadimefon & 0.351 & 1132 a & 85.6 & $36.4 \mathrm{c}$ & 25.5 & 1.0 \\
\hline Triadimefon & 0.701 & $1128 \mathrm{a}$ & 84.9 & $41.0 \mathrm{a}$ & 41.4 & 1.0 \\
\hline Benomyl & $0.55 \mathrm{~kg}$ & $1070 \mathrm{ab}$ & 75.4 & $41.3 \mathrm{a}$ & 42.4 & 1.0 \\
\hline Benomyl & $1.11 \mathrm{~kg}$ & $1024 \mathrm{~b}$ & 67.9 & $40.4 \mathrm{ab}$ & 39.3 & 1.0 \\
\hline Sulfur & $2.22 \mathrm{~kg}$ & $1014 \mathrm{~b}$ & 66.2 & $36.0 \mathrm{cdd}$ & 24.1 & 2.0 \\
\hline Sulfur & $3.33 \mathrm{~kg}$ & $1008 \mathrm{~b}$ & 65.2 & 38.2 bc & 31.7 & 2.0 \\
\hline Copper hydroxide & $1.11 \mathrm{~kg}$ & $574 \mathrm{~g}$ & -5.9 & $23.5 \mathrm{~g}$ & -19.0 & 2.8 \\
\hline Copper hydroxide & $2.22 \mathrm{~kg}$ & 656 ef & 7.5 & $25.0 \mathrm{fg}$ & -13.8 & 2.8 \\
\hline Chlorothalonil & 2.651 & $852 c$ & 39.7 & $33.7 \mathrm{~d}$ & 16.2 & 2.0 \\
\hline Chlorothalonil & 5.321 & $740 \mathrm{~d}$ & 21.3 & $28.8 \mathrm{e}$ & -0.7 & 2.0 \\
\hline Water & 3.781 & $616 \mathrm{fg}$ & 1.0 & $26.0 \mathrm{fg}$ & -10.3 & 3.0 \\
\hline Water & 7.561 & $690 \mathrm{de}$ & 13.1 & $27.3 \mathrm{ef}$ & -5.9 & 3.0 \\
\hline Check & & $610 \mathrm{fg}$ & & $29.0 \mathrm{e}$ & & 3.0 \\
\hline
\end{tabular}

'Mean of four replications.

'Mean values in same column bearing unlike letters differ significantly $(P<.05)$. 
In the first experiment (table 1), plants treated with triadimefon at $0.35 \mathrm{~L} / \mathrm{ha}$ produced a significantly higher number of fruits per plot (527) than any other treatment. Benomyl-treated plants produced a similar number of fruits/plot (442 and 437) at the two rates tested (0.55 and 1.11 $\mathrm{kg} / \mathrm{ha}$ ). Plants treated with triadimefon at $0.70 \mathrm{~L} / \mathrm{ha}$ produced significantly fewer fruits than those at the previous rate. Although there is no explanation, phytotoxicity seems a possible cause.

In terms of yield, triadimefon at $0.35 \mathrm{~L} / \mathrm{ha}$ also resulted in significantly higher yields than all the other treatments, whereas benomyl at the two rates tested, sulfur at $2.22 \mathrm{~kg}$ and dinocap at $0.42 \mathrm{~L} / \mathrm{ha}$ resulted in similar yields. Yield increments in the order of 45 and $24 \%$ were obtained in plots treated with triadimefon $(0.35 \mathrm{~L} / \mathrm{ha}$ ) and benomyl (both rates). Dinocap ( $0.42 \mathrm{~L} / \mathrm{ha})$ also increased yield by about $26 \%$, even though disease ratings were as high as those of the untreated plants. Apparently, other mechanisms might have been operating to protect the plant against this pathogen. A trend for yield reduction with increased concentrations of fungicide was observed. This finding suggests a deleterious effect with the higher dosages, particularly evident with triadimefon, copper hydroxide and dinocap.

In the second experiment, higher yields were obtained even though disease incidence was similar to that of the previous study (table 1). This suggests that optimal protection of peppers against powdery mildew will be obtained if treatments are initiated before infection and the appearance of visible foliar symptoms.

Treatments with triadimefon $(0.70 \mathrm{~L} / \mathrm{ha})$, benomyl (both rates) and sulfur (both rates) produced a higher yield of fruits/plot. However, in this experiment, the use of triadimefon at low dosage, resulting in 36.4 $\mathrm{kg}$ of fruits/plot, was not as effective as in the previous study.

Copper hydroxide again produced a deleterious effect similar to that observed previously. Plants treated with copper hydroxide yielded significantly fewer fruits than the controls. Water treatments were ineffective in controlling the pathogen as evidenced by the low number and weight of fruits, and by the high disease rating. Previous reports $(8,11)$ had suggested that since powdery mildews are diseases associated with dry seasons, aqueous foliar sprays might offer mildew control. In this experiment, water sprayed weekly and biweekly was likely insufficient to maintain the amount of free water at the leaf surface needed to prevent spore germination and external colonization by $L$. taurica.

The results of these experiments indicate that certain fungicides can be used for effective control of powdery mildew in peppers under Puerto Rico's conditions. Similar results have been reported by Ruppel et al. (9) and Kontaxis (4), who obtained good control of powdery mildew of sugarbeets with sulfux dust and wettable sulfur. Mathur et al. (5) lowered powdery mildew incidence in chili with a variety of sulfur formulations. 
Rao and Shanmugan (7) and Pawar et al. (6) reported optimal control of powdery mildew in peppers with 0.05 percent triadimefon. Even though $L$. taurica can be effectively controlled with fungicides, the risk of resistance when control depends only on chemicals warrants research with other varietal and cultural methods that, in combination with fungicides, may provide more effective and stable control.

\section{LITERATURE CITED}

1. Estación Experimental Agrícola. 1979. Conjunto tecnológico para la producción de hortalizas. Publ. 102. Esta. Exp. Agríc. Univ. P. R.

2. Departamento de Agricultura. Oficina de Estadisticas Agrícolas. Informe Anual 198485. Estado Libre Asociado de Puerto Rico, Santurce, Puerto Rico.

3. Dixon, G. R., 1978. Powdery mildews of vegetables and allied crops. Pages 495-519. In: D. M. Spencer (Ed), The Powdery Mildews. Academic Press, New York \& London.

4. Kontaxis, D. G., 1976. Chemical control of powdery mildew of sugarbeets. Calif. Agric. 30 (1): 13-4.

5. Mathur, R. L., G. Singh and R. B. L. Gupta, 1972. Chemical control of powdery mildew of chilly (Capsicum annum) caused by Leveillula taurica. Indian J. Mycol. Plant Pathol. 2: 182-83.

6. Pawar, R. N., P. G. Utikar and P. A. Shinde, 1985. Field evaluation economics of fungicidal control of powdery mildew, $L$. taurica (Lev) Arn, of chili. Pesticides 19 (8): $69-70$.

7. Rao, A. V., N. Shanmugan, 1986. Effective control of powclery mildew of chillies with triadimefon and biloxazol. Pesticides 20 (1): 25-6.

8. Rotem, J. and Y. Cohen, 1966. The relationship between mode of irrigation and severity of tomato foliage diseases in Israel. Plant Dis. Rep. 50: 635-39.

9. Ruppel, E. G., F. J. Hills and D. L. Mimford, 1975. Epidemiological observations on the sugarbeet powdery mildew in western U.S.A. in 1974. Plant Dis. Rep. 59: $283-86$.

10. Yarwood, C. E., 1939. Control of powdery mildews with a water spray. Phytopathology 29: 288-90.

11. Yarwood, C. E., 1957. Powdery Mildews. Bot. Rev. 23: 235-301. 